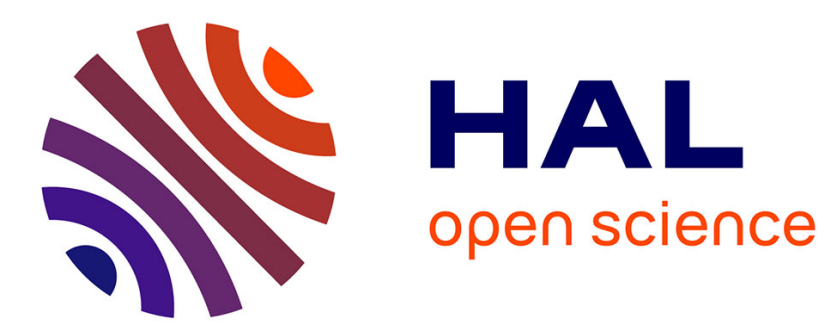

\title{
Global economic crisis, energy use, CO2 emissions, and policy roadmap amid COVID-19
}

\author{
Most Asikha Aktar, Md. Mahmudul Alam, Abul Quasem Al-Amin
}

\section{To cite this version:}

Most Asikha Aktar, Md. Mahmudul Alam, Abul Quasem Al-Amin. Global economic crisis, energy use, CO2 emissions, and policy roadmap amid COVID-19. Sustainable Production and Consumption, 2021, 26, pp.770-781. 10.1016/j.spc.2020.12.029 . hal-03520185

\section{HAL Id: hal-03520185 \\ https://hal.science/hal-03520185}

Submitted on 10 Jan 2022

HAL is a multi-disciplinary open access archive for the deposit and dissemination of scientific research documents, whether they are published or not. The documents may come from teaching and research institutions in France or abroad, or from public or private research centers.
L'archive ouverte pluridisciplinaire HAL, est destinée au dépôt et à la diffusion de documents scientifiques de niveau recherche, publiés ou non, émanant des établissements d'enseignement et de recherche français ou étrangers, des laboratoires publics ou privés. 


\title{
Global Economic Crisis, Energy Use, $\mathrm{CO}_{2}$ Emissions and Policy Roadmap amid COVID-19
}

\author{
Most. Asikha Aktar \\ Department of Economics, Comilla University \\ Cumilla, Bangladesh \\ Email: asikharita@gmail.com \\ Md. Mahmudul Alam * \\ School of Economics, Finance \& Banking \\ Universiti Utara Malaysia, Sintok, Kedah, Malaysia \\ Email: rony000@gmail.com \\ Abul Quasem Al-Amin* \\ Department of Geography and Environmental Management \\ University of Waterloo, Waterloo, ON Canada \\ Email: qalamin@uwaterloo.ca \\ *corresponding author
}

\section{Citation Reference:}

Aktar, M.A., Alam, M.M. \& Al-Amin, A.Q. (2021). Global Economic Crisis, Energy Use, CO2 Emissions and Policy Roadmap amid COVID-19. Sustainable Production and Consumption, 26, 770-781. (online) https://doi.org/10.1016/j.spc.2020.12.029

This is a pre-publication copy.

The published article is copyrighted by the publisher of the journal. 


\section{Global Economic Crisis, Energy Use, $\mathrm{CO}_{2}$ Emissions, and Policy Roadmap amid COVID-19}

\section{Highlights}

1. COVID-19 pandemic causes massive damage to global economic growth but improve climate condition

2. When the lockdowns will be lifted the global economic climate is expected to bounce back

3. Implementing green economic stimulus packages related to COVID-19 will create a systematic transition to a low carbon economy and society

4. Policy makers need to consider the triple crisis of economic, climate change and COVID19 pandemic at the same time

\section{Graphical Abstract}

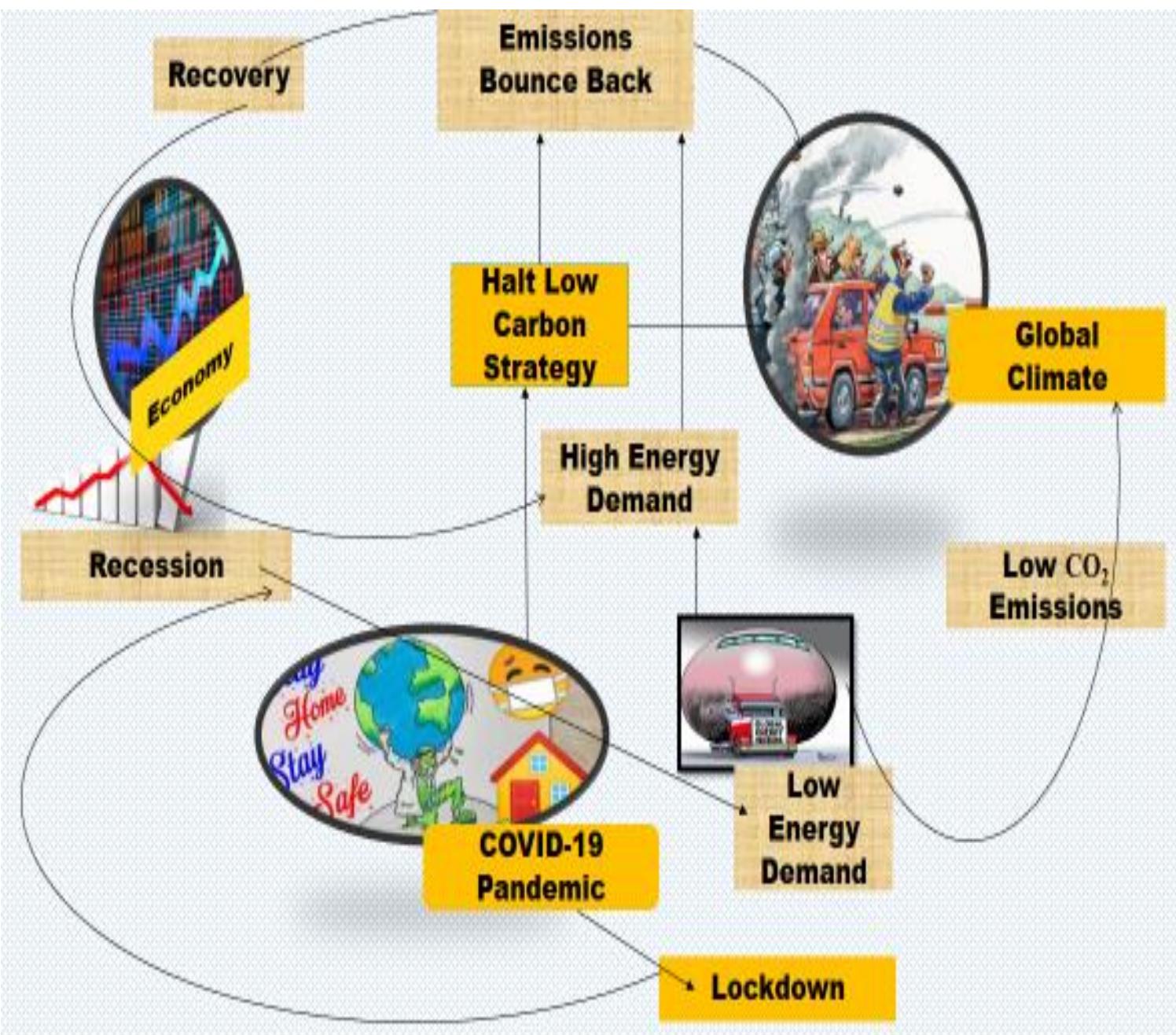




\title{
Global Economic Crisis, Energy Use, $\mathrm{CO}_{2}$ Emissions, and Policy Roadmap amid COVID-19
}

\begin{abstract}
The COVID-19 pandemic has emerged as one of the deadliest infectious diseases on the planet. Millions of people and businesses have been placed in lockdown where the main aim is to stop the spread of the virus. As an extreme phenomenon, the lockdown has triggered a global economic shock at an alarming pace, conveying sharp recessions for many countries. In the meantime, the lockdowns caused by the COVID-19 pandemic have drastically changed energy consumption patterns and reduced $\mathrm{CO}_{2}$ emissions throughout the world. Recent data released by the International Monetary Fund and International Energy Agency for 2020 further forecast that emissions will rebound in 2021. Still, the full impact of COVID-19 in terms of how long the crisis will be and how the consumption pattern of energy and the associated levels of $\mathrm{CO}_{2}$ emissions will be affected are unclear. This review aims to steer policymakers and governments of nations toward a better direction by providing a broad and convincing overview on the observed and likely impacts of the pandemic of COVID-19 on the world economy, world energy demand, and world energy-related $\mathrm{CO}_{2}$ emissions that may well emerge in the next few years. Indeed, given that immediate policy responses are required with equal urgency to address three things - pandemic, economic downturn, and climate crisis. This study outlines policy suggestions that can be used during these uncertain times as a guide.
\end{abstract}

Key Words: Economic Crisis; Energy Use; $\mathrm{CO}_{2}$ Emissions; Climate Change; Policy; COVID19

\section{Introduction}

The COVID-19 pandemic is inflicting destruction on many of the world's economies, triggering a global crisis in health and slowing international trade and commerce due to strict measures for quarantine (Harapan et al., 2020). Barring a few, most countries have entered conditions of stagnation responding to the pandemic. For a broad spectrum of global situations, estimated losses of global Gross Domestic Product (GDP) are likely to be between $1.3 \%$ and $5.8 \%$ in 2020 (McKibbin \& Fernando, 2020), although global economic impacts of the pandemic are highly uncertain (Yu \& Aviso, 2020). The Organization for Economic Cooperation and Development (OECD) and World Trade Organization have indicated that the COVID-19 pandemic is the largest warning for each nation globally since the 2008-2009 global financial crises (Sruthi, 2020). Some experts even suggest that the world did not experience such an unusual state of emergency since World War II (Chakraborty \& Maity, 2020).

Without a vaccine and no recognized operative treatment, the available tools are limited to social distancing, which consists of travel restrictions and quarantine-type arrangements. These instruments are the same as those available in Europe in the 13th century during the Black Death when the plague tore through most of Europe. To slow down the virus transmission, attempting to "flatten the curve," and avoid crippling their healthcare system, many countries have taken a comprehensive approach by imposing very strict limitations on the movement of people. By closing workplaces and shutting down manufacturing activities, limiting mobility in public places, closing non-essential stores, closing schools, closing borders, and limiting traffic (air, road, and sea), this policy has effectively shut down economic and social activities. This has come at a high social and economic cost, mainly in countries with an inadequate capacity to absorb sustained national "lockdowns" particularly in emerging and developing economies. Many businesses have been categorized as bankrupt or in need of 
government assistance. Joblessness is growing speedily and has destroyed the livelihoods of millions of vulnerable people mainly in emerging and developing economies. Recently, it has become known as a "Black Swan" event (Petro, 2020), and the resulting economics is called "Coronanomics" (Eichengreen, 2020).

Conversely, the social-distancing initiatives embraced by most governments have induced some positive outcomes for the world's climate (Dutheil et al., 2020). As such, an international research team reported that an extraordinary decline in $\mathrm{CO}_{2}(8.8 \%)$ emissions was observed in the first half of 2020 than in the same timeframe in 2019. It was a cumulative decrease of 1,551 million tons (Mavrokefalidis, 2020). This was a result of the reduced demand for power in industries and the decrease in the usage of public and private transport. This is nothing to celebrate; however, as one energy expert believes that if the strategies and policies for low-carbon development are not incorporated into the packages of economic stimulus designed to recover from the COVID-19 pandemic, emissions might rebound or exceed earlier estimated levels by 2030, regardless of the lower levels of economic growth (Climate Action Tracker, 2020).

The impact of COVID-19 on major countries has been heightened by numerous government studies and research reports while the drop in $\mathrm{CO}_{2}$ emissions presently found in a number of countries is only temporary (Mandal \& Pal, 2020). For the atmosphere, this is potentially good news, as the pandemic exposes the world to the possibilities of a protracted decarbonized environment (Watts, 2020). The author also stated that although global emissions have declined for the first time in 12 years, the end of the lockdown is predicted to make $\mathrm{CO}_{2}$ emissions bounce back. Soil erosion, deforestation, water and air contamination, safe domestic management, and absorbing waste from medical activities will encounter the worse problems in the wake of the current pandemic crisis. The resulting impact on the environment may last longer and perhaps be more challenging to control (Zambrano-Monserrate et al., 2020).

The debate on this situation continues (Paital, 2020). This pandemic, however, does not indicate any clear picture that responses to it can lead to permanent and significant changes in the forthcoming world economy and climate. Despite the significant role of $\mathrm{CO}_{2}$ emissions for estimating the global climate change, studies have not yet quantified how deep and long the global $\mathrm{CO}_{2}$ emissions cut will last due to the mounting economic damage caused by the pandemic (Paital, 2020). Keeping track of the ongoing economic crisis, an assessment of energy usage and $\mathrm{CO}_{2}$ emissions in this study not only provides a much more detailed look at the effects of COVID-19 on global climate change, it also proposes what necessary steps could be taken for managing future economic developments and climate change with the same urgency as tackling the COVID-19 pandemic.

The main purpose of this study is therefore not to deliver any quantitative estimation, but to provide a broad and suggestive overview on the observed and possible impacts of the COVID-19 pandemic on the world economy, world energy demand, and world energy-related $\mathrm{CO}_{2}$ emissions that may well emerge in the next few years. It also discusses the relevant policy guide in the global context. All authentic news sources along with systematic literature were sensibly analyzed to present objective conclusions on this subject. This study seeks to steer policymakers and countries' governments toward a better pathway as 'policy roadmap' by providing valuable information on the impact of the COVID-19 pandemic on the world economy, energy demand, and $\mathrm{CO}_{2}$ emissions and reference an adoption of new pathways. Finally, the facts presented here are expected to play a positive role in allowing practitioners, readers, and researchers to consider the contributions of low-carbon pathways to disease prevention and associated crises, and furthermore promote the near-future adoption of new pathways. 


\section{COVID-19 Pandemic}

Officially named on December 30, 2019, the disease known as COVID-19 was announced as a state of global concern by the World Health Organization on March 11, 2020 (WHO, 2020). Cases spread rapidly in January, initially through China's provinces, but spread rapidly between January (late) and February (mid) to Japan, particularly in Europe (largely Italy, France and Spain), South Korea, and irrevocably the United States before spreading a global scale by the phase the pandemic was confirmed (Sohrabi et al., 2020). Other rapidly infected bordering countries were Malaysia, the Philippines, Thailand, Singapore, and Vietnam (Silverstein et al., 2020; Guan et al., 2020; Pongpirul et al., 2020). In total, as per the report published by WHO (2020), more than 190 countries and regions across the world have been affected by the pandemic, and the identified confirmed cases were 50,676,072, including $1,261,075$ deaths as of November 10, 2020. It has affected everyone's lives throughout the world in many ways. However, these statistics are fluctuating every day.

By mid-February 2020, China suffered a massive burden of mortality and morbidity; during that time, the numbers remained low for the other Asian, European, and North American countries as well (Velavan \& Meyer, 2020). However, the pandemic moved very speedily to the European countries, and Italy emerged as the next great center of the pandemic. Currently, the USA tops the list, with confirmed numbers being 9,868,389 infected and 236,042 deaths as of November 10, 2020, making the country the largest sufferer of the pandemic. Meanwhile, India emerged as the second-largest sufferer of the pandemic, with 8,591,730 confirmed cases, including 127,059 deaths as of November 10, 2020. Figure 1 reports the world's worst affected countries by the number of highest confirmed cases where the cumulative total is at least 1 million or more than 1 million.

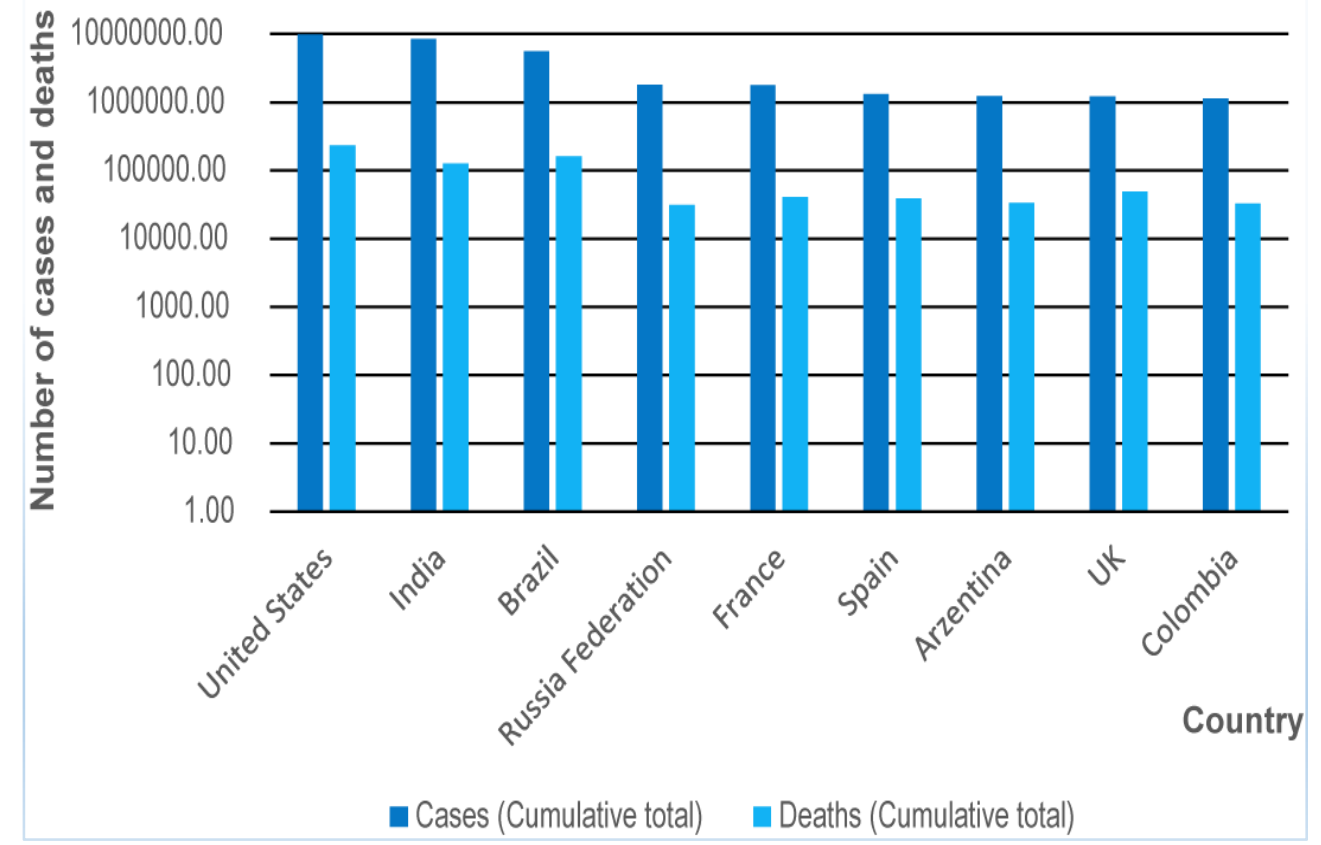

Figure 1: World's Top Countries by Number of Highest Cases

Source: WHO, 2020 (accessed on November 10, 2020)

According to the genomic analysis, COVID-19 is phylogenetically connected to severe acute respiratory syndrome (SARS)-like bat-transmitted or related viruses, so it is most likely that bats were the primary source of COVID-19 (Shakil et al., 2020; Chakraborty \& Maity, 2020). Although that the transitional basis of origin and transference to humans is not yet undoubtedly recognized, the human-to-human quick-circulating ability of this virus has been 
recognized (Chakraborty \& Maity, 2020). COVID-19 infection can cause mild fever at the initial stage, cough, and high fever at a later stage, problems in breathing, and in critical situations, SARS and pneumonia, heart attack, and consequently death. It usually spreads and triggers the clinical indications among the people who are infected within 14 days (Huang et al., 2020).

The morbidity rate is much more evident among the elderly and for those with comorbidities and underlying respiratory conditions, such as asthma and related lung diseases, kidney diseases, high blood pressure, cardiac diseases, diabetes, and cancer, among others. They no longer have immunity to fight this virus (Arabi et al., 2019; Dong et al., 2020b; WHO, 2020; Zhou et al., 2020; Ashour et al., 2020). So, far, there exists no exact and operative medication or vaccine for stopping COVID-19; therefore, lockdowns, including cluster lockdowns, social distancing, mass quarantine, and extensive travel bans, have been implemented as precautionary actions to restrain the transmission of COVID-19 (Paital et al., 2020; Das \& Paital, 2020). Such extreme measures for controlling the pandemic have had the straightforward effect of damaging countries' economic and socio-political fabric, representing a worldwide pandemic threat (Chakraborty \& Maity, 2020).

\section{The Economic Impact of COVID-19}

Equated to the economic damage caused by World War II (Watts, 2020) in addition to being regarded as a "Black Swan" event (Deloitte Insights, 2020), the eruption of the COVID-19 pandemic has severely wrecked worldwide economy. Some analysts have predicted that travel restrictions, border shutdowns, and quarantine measures imposed by governments in an effort to "flatten the pandemic curve" (Burkert \& Loeb, 2020) have generated justified worries of a looming economic recession and long-lasting crisis (Buck et al., 2020). The economic loss caused by the COVID-19 pandemic is mainly due to a decrease in demand for many goods and services. This means that there are not enough customers in the global economy to buy goods and services.

According to Asian Development Bank (ADB) (2020a), as of June 1, 2020, the estimated range of domestic demand declined, resulting from a significant domestic outbreak (defined as >1,000 COVID-19 cases) relative to a no-COVID baseline scenario for a country such as Bangladesh (7.70\%-11.55\%), followed by Pakistan (7.26\%-10.89\%) and India $(6.40 \%-9.60 \%)$. This dynamic is clearly seen in the sectors, which have suffered the most (Figure 2). People cannot buy flights for business or holiday trips as a result of travel restrictions or closures enacted by countries to stop the virus's spread throughout the world. This decline in customer demand forced airlines to lose their expected sales levels, which in turn reduced the total number of aircraft flown. Without any government support, airlines will eventually cut staff numbers to further reduce costs.

This trend is virtually the same for all other sectors of the economy. The fear is that this will turn the economy into a lower loop as these new unemployed workers can no longer afford to buy goods and services and live within their means, among others, when industries start to cut staff numbers in order to compensate for lost sales and business. Di Mauro (2020) defines such upshots as the "macroeconomic flu"-a transitory destructive shock to demand and supply as well as triggering falls in the output that quickly recovers, and the damage is probably fully recovered. However, that occurs when it is like a macroeconomic sneeze or a common flu, but unlike the COVID-19 pandemic, which is clearly causing endless global economic destruction on a large scale (Di Mauro, 2020).

Economists agree that the COVID-19 pandemic will have a destructive impact on the world's economy, although there is no definite way to say precisely what the damage will be (Brakman et al., 2020). The International Monetary Fund (IMF) and the World Bank (WB) both project that advanced economies will fall by $7 \%$ and $6 \%$, respectively, as a sharp 
contraction of financial situations, extensive social-distancing measures, and a fall in external demand that deteriorates activity (Murphy-Gregory, 2018.). The GDP of Emerging Market and Developing Economics (EMDE) is projected to shrink by $2.5 \%$ and $1.0 \%$ in 2020 because of the negative supply shocks from weakness in advanced economies, along with the distractions allied with their own domestic outbursts, probably causing millions of people to fall back into poverty.

(A)

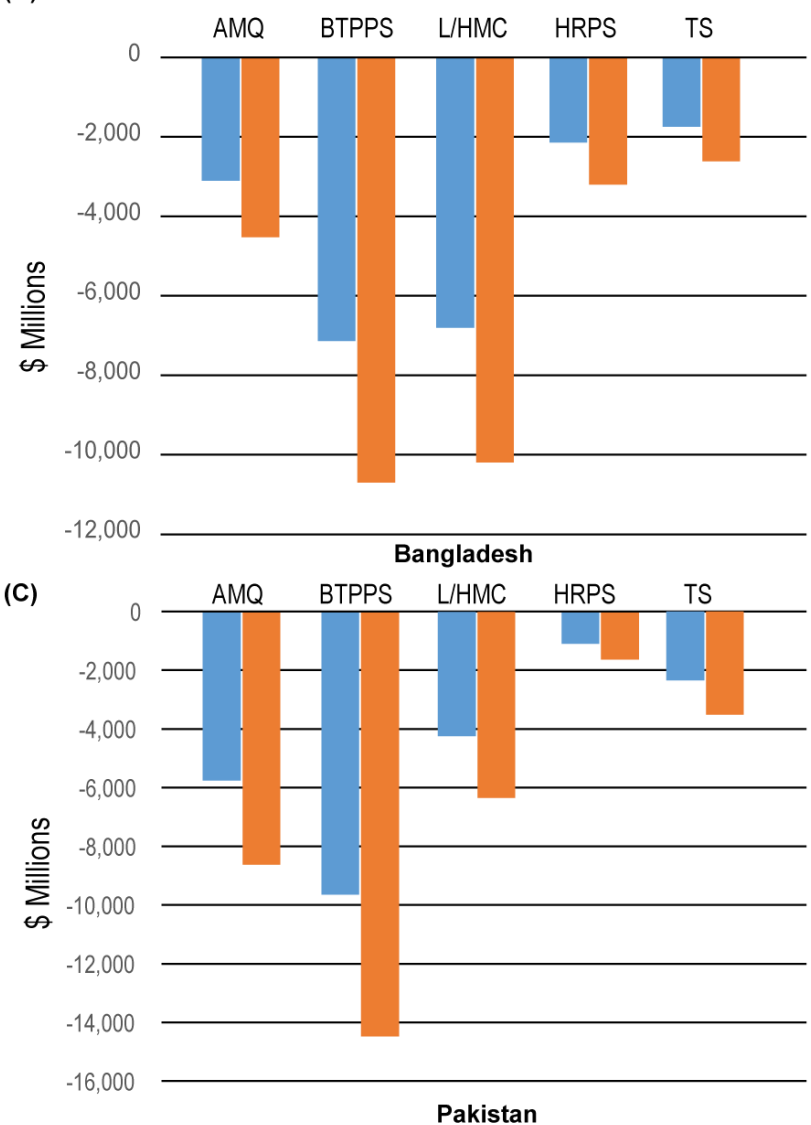

(B)

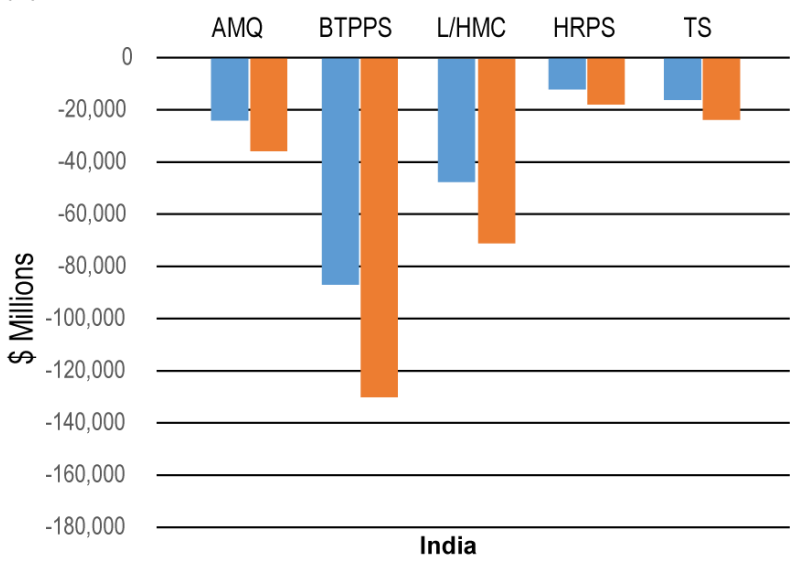

Legends:

Shorter- containment scenario

Longer- containment scenario

Sectors:

$A M Q--A g r i c u l t u r e$, mining and quarrying

BTPPS--Business, trade, personal and public services L/HMC--Light/heavy manufacturing \& construction HRPS--Hotel, restaurants and other personal services TS--Transport services

Figure 2: Sectoral losses caused by the decline in consumer demand induced by COVID-19

Source: ADB, 2020a

Particularly, vulnerable EMDEs include Middle East, Sub-Saharan Africa, North Africa, Eastern Europe, Caribbean Latin, America and Central Asia (World Bank, 2020). As these four regions are major oil exporters, they are at the mercy of severe drops in oil prices (see Table 1).

Table 1: Growth Projections (Real GDP, Change of Percent Annually)

\begin{tabular}{|l|c|c|c|c|c|c|}
\hline \multirow{2}{*}{ World output } & \multicolumn{2}{|c|}{2019} & \multicolumn{2}{c|}{2020} & \multicolumn{2}{c|}{2021} \\
\cline { 2 - 7 } & WB & IMF & WB & IMF & WB & IMF \\
\hline Developed Economies & 2.9 & 2.4 & -3.0 & -5.2 & 5.8 & 4.2 \\
\hline \multicolumn{1}{|c}{ United States } & 1.7 & 1.6 & -6.1 & -7.0 & 4.5 & 3.9 \\
\hline$\quad$ Euro Area & 2.3 & 2.3 & -5.9 & -6.1 & 4.7 & 4.0 \\
\hline$\quad$ Japan & 1.2 & 1.2 & -7.5 & -9.1 & 4.7 & 4.5 \\
\hline Emerging Markets and & 0.7 & 0.7 & -5.2 & -6.1 & 3.0 & 2.5 \\
\hline Economies & 3.7 & 3.5 & -1.0 & -2.5 & 6.6 & 4.6 \\
\hline$\quad$ East Asia and Pacific & 5.5 & 5.9 & 1.0 & 0.5 & 8.5 & 6.6 \\
\hline Europe and Central Asia & 2.1 & 2.2 & -5.2 & -4.7 & 4.2 & 3.6 \\
\hline
\end{tabular}




\begin{tabular}{|c|c|c|c|c|c|c|}
\hline $\begin{array}{c}\text { Latin America and the } \\
\text { Caribbean }\end{array}$ & 0.1 & 0.8 & -5.2 & -7.2 & 3.4 & 2.8 \\
\hline $\begin{array}{c}\text { Middle East and North } \\
\text { Africa }\end{array}$ & 1.2 & -0.2 & -2.8 & -4.2 & 4.0 & 2.3 \\
\hline Sub-Saharan Africa & 3.1 & 2.2 & -1.6 & -2.8 & 4.1 & 3.1 \\
\hline
\end{tabular}

Source: World Bank, 2020b; International Monetary Fund, 2020

Followed by a more severe contraction of advanced economics and ravaged emerging and developing economics, the world GDP is projected to fall by $5.2 \%$ this year based on the projections of the WB, while the IMF projects a 3\% reduction of the global GDP. It is now an inevitable conclusion that the global economy in 2020 will slip into the world's worst recession since World War II, and nearly threefold as steep as the recent world recession of 2009 (World Bank, 2020b). As such, the COVID-19 pandemic has already begun, leading to a sharp reduction in global trade $(-13.4 \%)$, and a dramatic reduction of most commodity prices, especially a huge fall in oil prices $(-47.9 \%)$ in 2020 (World Bank, 2020b).

While a modest recovery of global growth is anticipated to be at $4.2 \%$ by the WB and $5.8 \%$ by the IMF in 2021, it is hoped that the pandemic may have a clear end date when all the restrictions on movement can be lifted, and a sharp rebound in the global economy will be possible (World Bank, 2020b). However, the strength of the anticipated rebound is uncertain. The longer that lockdowns last, the more structurally the economy is likely to be crippled, and the rebound will be weaker after 2020. In effect, a fall in demand would be even greater than the supply shock. The prediction is that if the global lockdown is extended by $50 \%$, the tighter financial conditions and heavier fiscal burdens resulting in economic impact will be severe and shrink the global economy by an additional 3\% in 2020 (Loayza, 2020).

However, experience shows that even if the virus appears to be under control, the economy will not recover quickly in the following quarter (Erken et al., 2020). This implies that the GDP growth curve will not essentially be in the form of a V-shaped phenomenon (i.e., a sharp decline in GDP growth in 2020 and then a sharp rise in GDP growth in 2021). While the "extended lockdown" scenario indicates that growth is now expected to be U-shaped (i.e., a longer-lasting runway prior to the economy recovering to its former level of output), Wshaped (where the economy rises and falls twice after its first recovery, prior to returning to its original state), or even L-shaped (where the GDP growth level not only be lower permanently but also be much more depressed unless bold action is taken by governments). If nothing good happens, sluggish activity will become entrenched.

\section{Impact on Global Energy Consumption}

In September 2015, 193 countries, from both emerging and developed countries, officially known as the agenda for Global Development of Sustainable Development Goals (SDGs) 2030 and Corporations, signed the SDGs devised by the United Nations (United Nations, 2015; Omer \& Noguchi, 2020; Ahmad \& Zhang, 2020). The importance of energy as one of the main pillars to ensure sustainable and inclusive economic development for each nation throughout the world has received considerable attention (Pietrosemoli \& Rodríguez-Monroy, 2019). Comprising the latest state-of-the-art, the world's use of energy grew exponentially in 19952015, rising from 8,588.9 to 13,147.3 million tons (Mtoe) (Ahmad \& Zhang, 2020; Dong et al., 2020a). On the contrary, many potential global energy projecting research works (Cooperation, 2015) have been investigated by several government agencies, such as the World Energy Council (Ahmad \& Zhang, 2020), the Organization of Petroleum Exporting Countries (Zuberi, 2011), the International Energy Agency (IEA), and world mega-oil organizations (Kohl, 2019). 
Due to a rapid shift in demand for coal to power production and manufacturing, all the respected agencies expect a rapid rise in energy usage for the near future (Ahmad \& Zhang, 2020). For instance, by 2040, non-OECD states are expected to be responsible for $64.0 \%$ of the total world energy requirements of 739 billion Btu (IEA, 2017). The largest change in energy usage in non-OECD countries is expected to be in Asia (IEA, 2017). For example, the total energy requirement of China will double by 2040, while India is expected to increase the world's energy needs by around $25.0 \%$ by 2040 (Ahmad \& Zhang, 2020). The increasing demand for global energy in a wide range of contexts will allow the catastrophic effects of global warming to continue unabated, although countries have signed up to come across the goal of the Paris Agreement and keep temperature rises below $2^{\circ} \mathrm{C}$ (IEA, 2017; Kona et al., 2018).

One of the noticeable impacts of COVID-19 is on global climate, which will recover to some extent due to the drop in consumption of energy (Saadat et al., 2020). The change in the production share of GDP output induced by the pandemic has resulted in critical variations in energy and consumption needs. The rapid implementation of global lockdowns within a few months meant that the global energy demand, especially for coal, oil, and gas declined steeply (McGrath, 2020). According to the IEA (2020a) report, a 25\% drop in energy demand on average per week is faced by nations with a full lockdown, while a partial lockdown demand for energy has declined by $18 \%$ on average per week. Though domestic demand for electricity has risen by $40 \%$ as millions of citizens are now confined to their residences, this has been far outweighed by the reduced demand for electricity in the commercial and industrial sectors (Broom, 2020).

The full lockdown per month reduced electricity demand by an average of $20 \%$ or $1.5 \%$ on an annual basis. As the first nation to implement social lockdown, electricity demand in China dropped in the first quarter by $6.5 \%$. Italy, India, France, Spain, the north-western region of the United States, and the United Kingdom all saw a drop in lockdown consumption of at least $15 \%$, while the electricity demand in Italy dropped by as much as $75 \%$ when the pandemic was at its peak (see Figure 3).

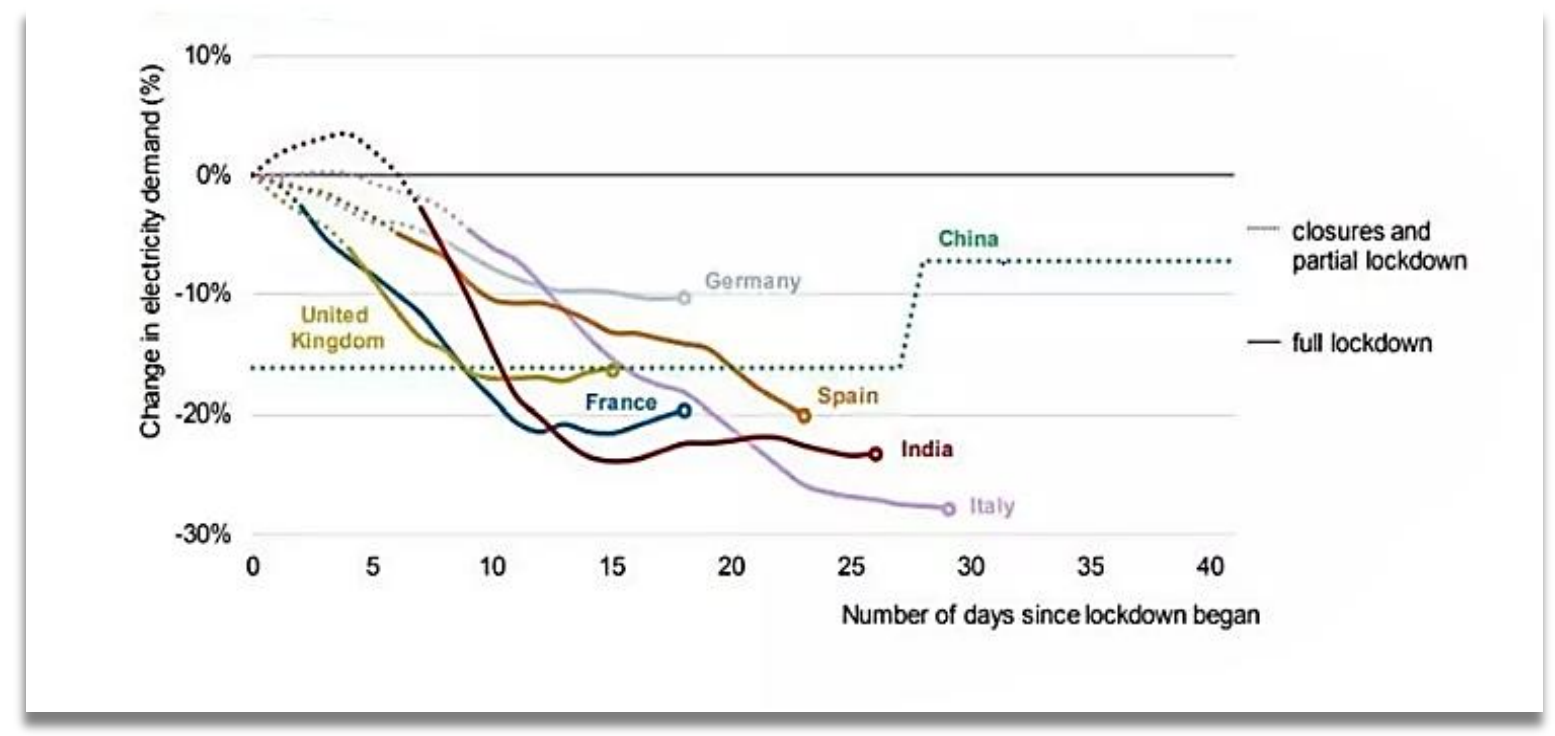

Figure 3: Electricity demand reductions after lockdown measures have been introduced in selected areas; weather corrected

Source: IEA, 2020b 
Based on a full year projection for 2020 by IEA (2020b), overall electricity demand is expected to fall by $5 \%$ this year, and this would be eight times greater than the impact triggered by the GFC. Therefore, the changing demand for electricity will have a knock-on consequence on the global coal requirement, which may well drop by $7.7 \%$ relative to 2019 's total demand (Figure 4). Due to the declining demand for electricity and industrial applications, demand for gas may also fall sharply compared with the first quarter of 2019. As for the first quarter of 2019, global primary energy demand for gas in 2020 will be expected to decline by $5 \%$ compared with the demand estimates for 2019. Equally, during 2019-2020, the expected percentage shift in primary energy demand for oil will decrease by $9.1 \%$.

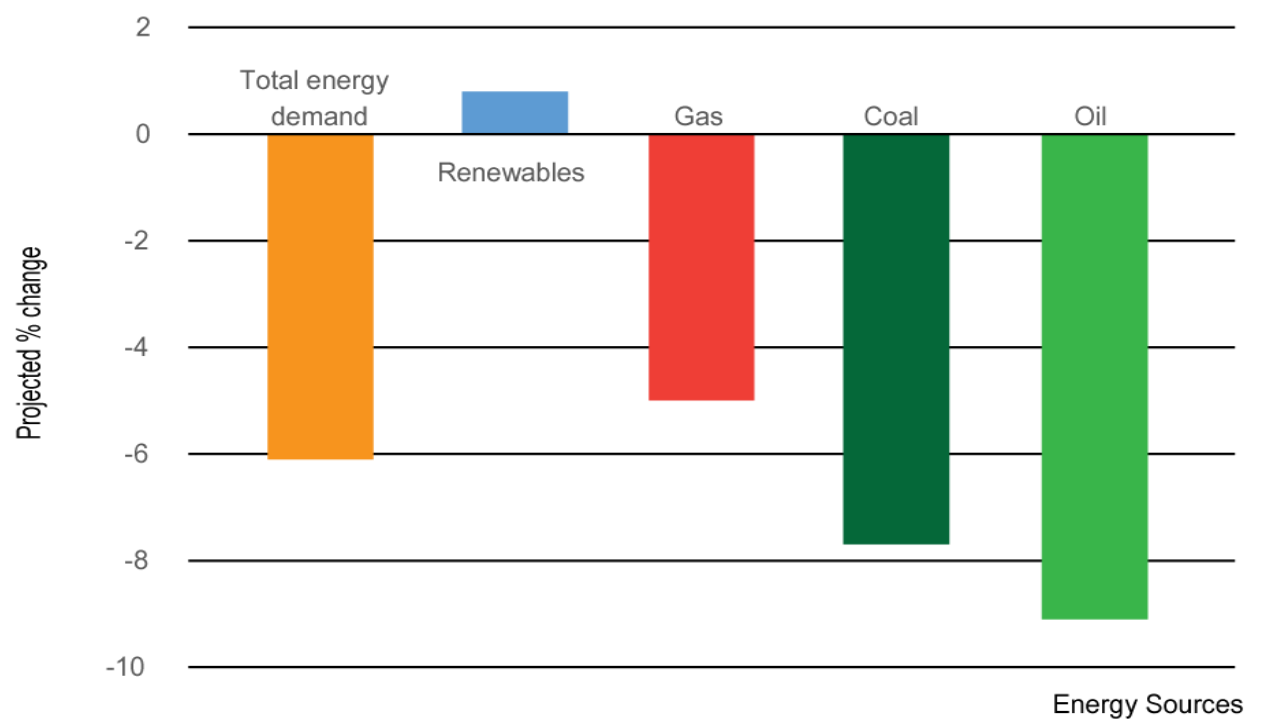

Figure 4: Projected percent change in worldwide demand for primary energy between 2019 and 2020, by energy source

Source: Sönnichsen, 2020

Moreover, the demand for renewable energy may increase for many operating systems, which is made possible by lower operating costs and preferred access. Even the demand for renewables will probably rise irrespective of how long the global lockdown lasts or if there is a second wave of the pandemic (The Indian Express, 2020). Considering the importance of renewable energy as the most resilient energy source during this COVID-19 lockdown era; however, the total global usage of renewable energy is likely to increase by $0.8 \%$ in 2020 . As a whole, the IEA projection for 2020 stated that less than $6 \%$ energy will be used worldwide in 2020 compared with 2019 (IEA, 2020b). Furthermore, the resulting impact would be seven times larger than the GFC of 2008-2009, even if lockdowns were lifted more extensively.

\section{Impact on Global Energy-Related $\mathrm{CO}_{2}$ Emissions}

$\mathrm{CO}_{2}$ emissions, contributed mainly by the energy sector, are one of the largest contributing factors to warm up the global climate (IPCC, 2014). The fifth evaluation report of the Intergovernmental Panel on Climate Change (IPCC) known as AR5 clearly demonstrates that the world is continuing to warm up due to the increasing concentration of fossil fuel energyrelated $\mathrm{CO}_{2}$ emissions (IPCC, 2014). Indeed, with the aim of stopping global warming, 196 countries signed the Paris Agreement, and they agreed to take action to restrict the rise in global surface temperature over pre-industrial levels to below $2^{\circ} \mathrm{C}\left(3.6^{\circ} \mathrm{F}\right)$. The hope is to restrict the rise to $1.5^{\circ} \mathrm{C}\left(2.7^{\circ} \mathrm{F}\right)$ (Mulvaney, 2019). Each signatory submits its own national plan under the Agreement, therefore setting emission reduction targets and defining the routes through which it seeks to achieve those targets. 
In spite of some nations' commendable efforts, $\mathrm{CO}_{2}$ emissions have not abated throughout the world, making this one of the most critical decades of modern times. Global $\mathrm{CO}_{2}$ emissions increased by $1.7 \%$ in 2017, having flattened between 2014 and 2016, and a further increase to $2.7 \%$ in 2018 (Mulvaney, 2019), with no growth in 2019 (Peters, 2020; IEA, 2019). Even though renewable energy production increased rapidly in 2019 in the midst of falling prices (Figueres, 2018), most of the renewable energy was utilized combined with fossil energy without replacing it (Le Quéré, 2019), while surface transport emissions continued to rise (Peters, 2020; Solaymani, 2019). Countries' economies and the livelihoods of billions of people are now put at risk by increasing pollution. With an imminent economic recession caused by the COVID-19 pandemic, a number of nations around the world are experiencing a reduction of $\mathrm{CO}_{2}$ emissions in 2020 as much as greater than $40 \%$ than the previous year as a result of new constraints to "flatten the curve" of the COVID-19 pandemic, and bring the pandemic under control (Paital, 2020).

According to IEA (2020c), in the $1^{\text {st }}$ quarter of 2020, the most carbon-intensive fuels go with the largest plunge in demand, and $\mathrm{CO}_{2}$ emissions declined further than the collapse in global demand for energy. Global emissions fell by more than $5 \%$ during the first quarter of 2019 to 2020 mainly to reduce emissions from coal by $8 \%$, from oil by $4.5 \%$, and from natural gas by $2.3 \%$ (IEA, 2020c). The regions with the highest emission reductions are USA $(-9 \%)$, China $(-8 \%)$, and the European Union (EU; $-8 \%$ ), which were the world's top emitters of $\mathrm{CO}_{2}$ and the mostly affected nations with COVID-19 (IEA, 2020c).

A range of studies has further stated that measures imposed by governments across the world have attempted, primarily, to identify cases and prevent virus diffusion and to thereby, reduce the speed of its extent. These governments are now making sweeping changes to policy and energy use, with likely effects on $\mathrm{CO}_{2}$ emissions (Le Quéré et al., 2020). If some limitations exist worldwide until the end of this year, the world will then attain nearly $8 \%$ lower emissions across this year than 2019 (IEA, 2020c), while the $-3 \%$ reduction projections of the IMF for 2020 in the global GDP will lead to $-5.7 \%$ reduced $\mathrm{CO}_{2}$ emissions in 2020 (IMF, 2020). This will be the smallest amount since 2010. Following the GFC, such a decrease will be the biggest ever, six times higher than the earlier record decrease of $0.4 \mathrm{Gt}$ in 2009 and since the end of World War II it double the average (cumulative) of all earlier reductions (IEA, 2020c).

A number of events for the past 100 years (Figure 5) have revealed that dramatic drops in $\mathrm{CO}_{2}$ emissions are possible. Much is made of the impact of the 1918 flu pandemic in 19181920. However, around $0.8 \mathrm{Gt}$ of $\mathrm{CO}_{2}$ emission reductions occurred between the stated periods. This is far less than the drop in $\mathrm{CO}_{2}$ during World War II, which has seen a drop of around 1.3 Gt. During the current COVID-19 pandemic, $\mathrm{CO}_{2}$ emission decreased by around $2.6 \mathrm{Gt}$. Yet, the figure shows that the economic fallout of COVID-19 in 2020 dwarves all of these earlier crises to some extent. It is noticeable that the induced economic crisis accompanying the COVID-19 pandemic differs from the earlier economic emergencies in the sense that it is felt more intensely in controlled human behavior (Mostafa et al., 2020; Le Quéré et al., 2020). 


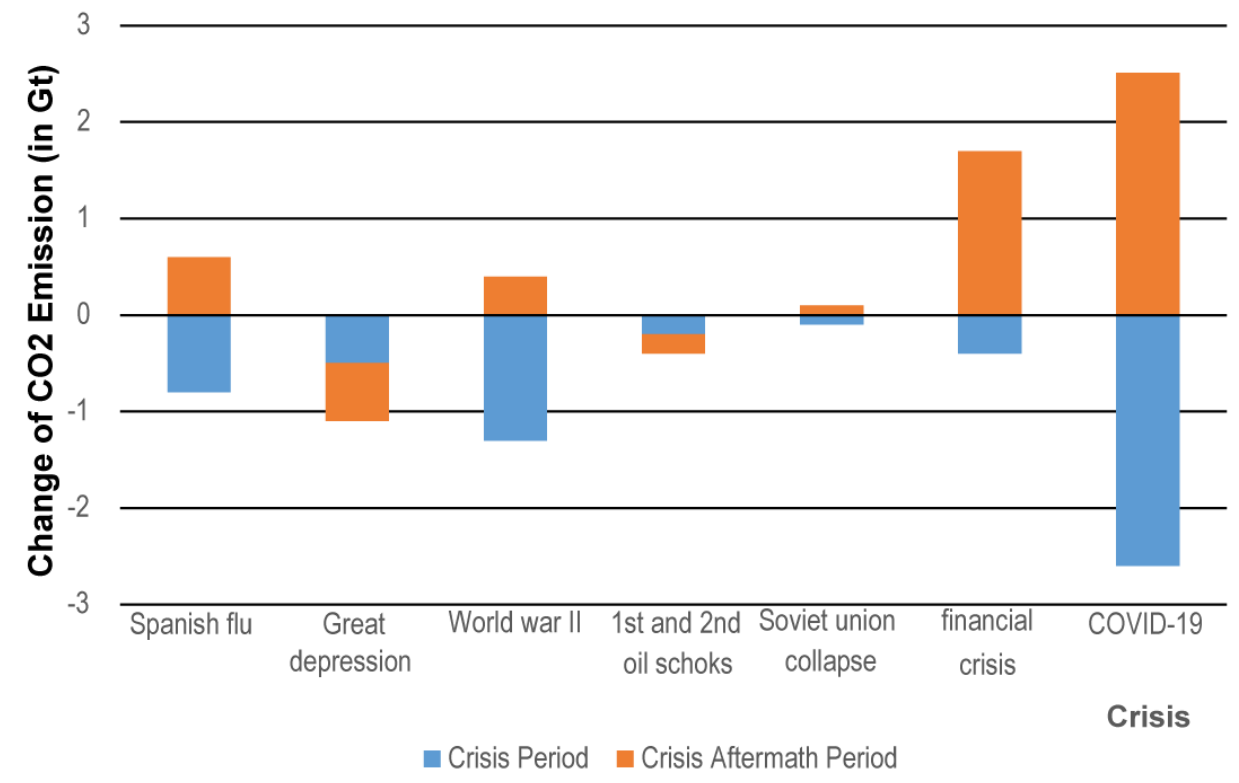

Figure 5: Changes of Global Energy-Related $\mathrm{CO}_{2}$ Emission (Gt) during different crises and the crisis aftermath period

Source: IEA, 2020c

If this declining pattern is further sustained, a climate model developed by the US Environmental Protection Agency forecasts that the fall in temperature in 2100 would be slightly above $0.1{ }^{\circ} \mathrm{C}$ (Financial Times, 2020). It is not obvious, however, whether this declining pattern will be sustained or otherwise. The experience of the previous economic crisis indicates that with the post-crisis recovery, the emissions returned to their original course. The fall in emissions was short-term, with the exception of the Great Depression, and when such crises were triggered by energy issues such as the 1970s and 1980s oil crises, they contributed to major improvements in the production of renewable sources of energy and energy efficiency (Peters et al., 2011). The GFC of 2008-2009, for example, saw a swift drop in global $\mathrm{CO}_{2}$ emissions of $-0.4 \mathrm{Gt}$ in 2009 , followed by a rise in emissions of $+1.7 \mathrm{Gt}$ in 2010 (IEA, 2020c), leading to a record high. Emissions rapidly returned as if there was no crisis to their former route. "There are hints that coronavirus will act the same way," stated Julia Pongratz, professor at the University of Munich, Department of Geography, Germany (Henriques, 2020). There will be an emission "bounce back" effect, and the outcome could be even worse due to the amount of energy consumed and associated levels of $\mathrm{CO}_{2}$ emissions, which are likely to surpass the level prior to the pandemic (Barboza, 2020).

Meanwhile, the previously noted Pongratz says it is hard to predict whether emissions will bounce back or not, but suggests a factor to determine whether the emissions will do so in the duration of the pandemic: if the pandemic lasts until the end of the year, due to lost wages, consumer demand could remain low; production and the usage level of fossil energy might not recover so fast, even though there is the potential to do so (Henriques, 2020). Moreover, preliminary discussion shows that the full effects of COVID-19 to reduce $\mathrm{CO}_{2}$ emissions are still unknown. This is despite the IMF and IEA further projecting that emissions for the world and US economies will rebound by $+5.8 \%$ and $+3.5 \%$ in 2021 , respectively (Le Quéré et al., 2020).

6. COVID-19 Pandemic, Global Economic Crisis, Energy Use, and $\mathrm{CO}_{2}$ Emissions Nexus There are a number of channels by which an infectious disease can affect the economy (i.e., direct and indirect). In spite of having a relatively small number of deaths and cases, estimates 
of the macroeconomic effects of the 2003 SARS outbreak reported that it did have a substantial impact on economies by dramatically reducing the consumption of different goods and services, raising the operational expenses of business, and reevaluating the risks of a region that led to higher risk premiums (Lee \& McKibbin, 2004). Studies by Siu and Wong (2004), Hai et al. (2004), Chou et al. (2004) and Bloom et al. (2005) estimated the potential economic impact of highly infectious diseases for which no vaccine is available (e.g., pandemic influenza, HIV/AIDS, and SARS). It is very evident that COVID-19 is also a very infectious and economy-wrecking pandemic.

The pandemic is the greatest economic shock experienced by the world economy in decades, causing global activity to crash. Actions to restrict the spread of the virus-for example, countrywide lockdowns, interruptions of human mobility, restricting transport use, and closure of industries-plunged whole regions into an economic recession in 2020, shrinking their economics to the extent suffered in the 1870s Great Depression (World Bank, 2020b). The pandemic and government mitigation strategies have sharply curtailed fossil fuel usage and the demand for conventional energy as a result of reduced electricity consumption since industries have simply ceased operating. Therefore, the global climate has been stabilizing due to the fall in $\mathrm{CO}_{2}$ emissions. Thus, the pandemic has contrasting consequences for human civilization: it has wreaked worldwide economic destruction but also led to a much more decarbonized world (Chakraborty \& Maity, 2020).

The fear is that most of the changes seen in 2020 are expected to be transient because they do not reflect systematic long-term changes in the energy systems, transportation, or economics. The societal stress of lockdown and related adjustments could change how economic recovery occurs in unexpected ways (McCollum, 2020), but the intense and persistent declines required to achieve net-zero emissions only for the time being will not be derived by the social reactions alone. Once lockdowns are removed, shuttered factories will reopen, and the global economy will return to what it once was, then emissions will rise again (McCloskey \& Heymann, 2020). It is already evident in some parts of China where the lockdown has been lifted for some months; enterprises are again taking up production and people and goods have started to flow on a large scale. In the meantime, the congestion of traffic is steadily returning to the pre-quarantine level, and consumption of energy is showing an upward trend. Based on this fact, when the whole of China will be completely free from lockdown and restarts economic activities, the consumption of energy will result in higher emissions that surpass the former level prior to the outbreak because businesses want to return to pre-COVID-19 conditions as rapidly as possible.

It has emerged that the crisis of COVID-19 threatens both local and global efforts to meet already made climate commitments by national governments (Climate Action Tracker, 2020). For instance, pressured to delay significant climate change measures, the EU called on Poland to suspend its carbon-trading program and the Czech Republic to abandon the EU's landmark climate bill, while airline firms pressured regulatory bodies to postpone emissionscutting policies. Such delays, extended time limits for companies to comply with environmental standards, and postponed auctions for the right to build a number of large solar farms have been announced by China. Thus, countries are trying to arrange their economic stimulus packages by diverting their resources originally marked for climate change mitigation to address the pandemic instead. This overall nexus is illustrated in Figure 6, which depicts the pandemic-driven global economic crisis, energy use, and $\mathrm{CO}_{2}$ emissions.

Despite the virus-triggered economic slowdown, $\mathrm{CO}_{2}$ emissions continue to be emitted in 2020. According to the World Meteorological Organization, the levels of $\mathrm{CO}_{2}$ are still at a record high in the atmosphere (Stylianou et al., 2020). The world is still releasing $80 \%$ more $\mathrm{CO}_{2}$ emissions than even before (McGrath, 2020). That is a huge amount, and to limit warming above pre-industrial temperatures and to keep it below $1.5^{\circ} \mathrm{C}$, it is necessary to reduce global 
emissions by $7.6 \%$ (e.g., about 2,800 $\mathrm{Mt} \mathrm{CO}_{2}$ per year (Evans, 2020). Yet, any emission cuts due to the COVID-19 pandemic in 2020 will only have very little effect on the total concentrations of $\mathrm{CO}_{2}$ emissions that have entered the atmosphere in a shorter period of time. Though our immediate vision is to fight COVID-19, the climate crisis is still a reality and must be solved.

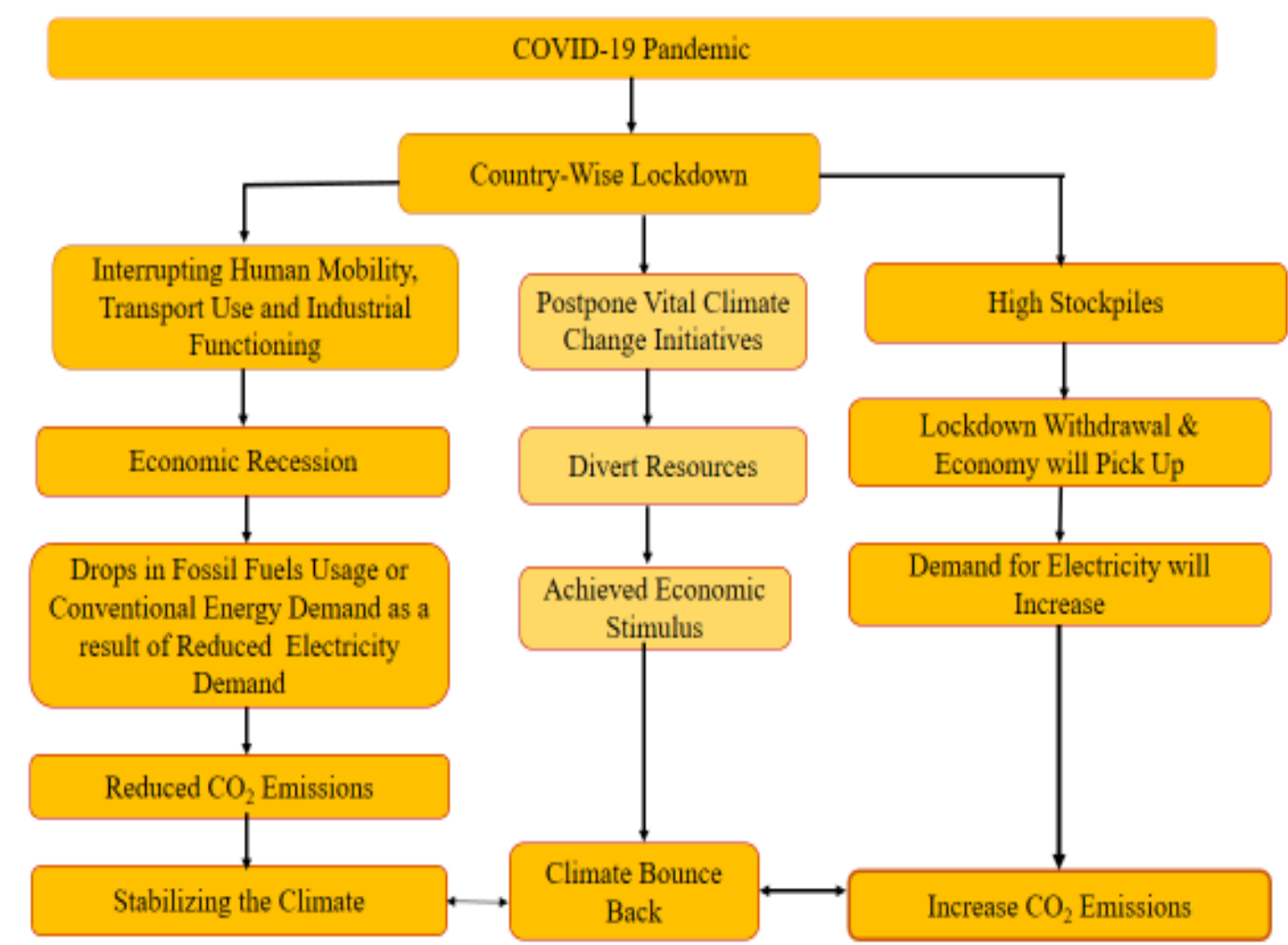

Figure 6: Nexus between pandemic-driven global economic crisis, energy use, and $\mathrm{CO}_{2}$ emissions

Source: Developed by Authors

\section{Policy Roadmap}

Although the location, strength, and immediacy of the effects of COVID-19 and climate crisis are not equal, both crises constitute unexpected coercions to human prosperity. The mutual dependence between pandemics, economic downturns, and climate crisis shows that, the deeper and longer these crises are, the more pernicious their combined impact is. This is why the scientific research community believes that both cases need urgent policy responses.

Both economists and policymakers agree that it is not easy to address the triple crisis of economic collapse, climate change, and COVID-19 using the usual macroeconomic tools (Baldwin \& Di Mauro, 2020; Letzing, 2020). Governments are currently implementing economic recovery programs, such as cash transfers, reducing the interest rate, or postponing loan repayments as a way to circumvent the damage caused by the COVID-19 pandemic. The main goal of this program is to alleviate widespread unemployment/underemployment and to rebuild key sectors of the economy. Such initiatives, however, run the risk of avoiding the reality of climate change and global warming. In its position as a government advisory body, the German Council of Economic Experts, for example, submitted a 110-page evaluation and policy document on March 2020 without even a single reference to climate or sustainability (GCEE, 2020). Pandemic response funds may be channeled into carbon-intensive sectors by decision-makers, giving support to status quo trajectories. For example, the USA's Trump 
government was prepared to bail out the country's fossil fuel industry (Krugman, 2020). Similar considerations are being made by the Canadian government (Fife et al., 2020). Such responses are, in the long run, unwise.

Societies should not divert their resources from low-carbon projects but rather harness the COVID-19 pandemic in order to hasten the ideal of a low-carbon world economy. The key underlying principle is that our natural resources are finite, and we are dealing with several simultaneous crises. Considering this reality, policymakers will do well to learn from the COVID-19 pandemic and use this time to set in motion new types of economic stimulus associated with low-carbon pathways (Rosenbloom et al., 2020). The possibilities of this are depicted in Figure 7.

As indicated in Figure 7, a starting point to low-carbon pathways are the "green" stimulus packages that can help achieve economic and climate objectives in the national agenda. Here, it should be noted that unless sustainability practices in production and consumption are not improved or more importantly, changed, then growing, but the same kind of consumption levels would offset any technological or environmentally friendly advances. At minimum, the policy plan and recommendations should be designed with a global coordination in mind. This study suggests that both innovations in low-carbon technology and sustainability approaches in production and consumption along with global coordination can help strike a balance between policy responses and low-carbon pathways, as depicted below.

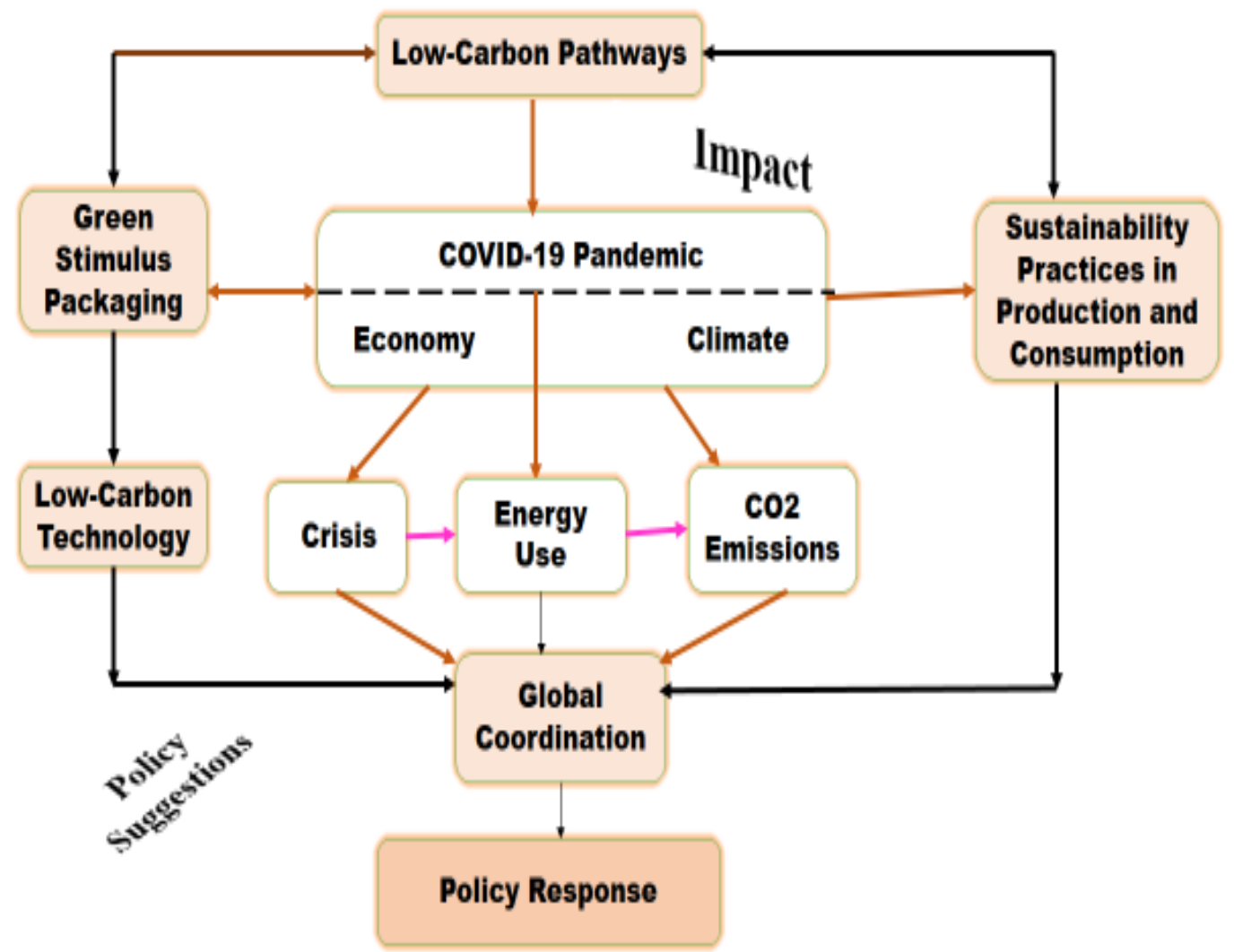

Figure 7: Key policy suggestions for linking policy responses and low-carbon pathways Source: Developed by Authors

\subsection{Green Stimulus packaging}

The COVID-19 pandemic demands resources on a massive scale in order for societies to continue functioning. Many nations are now facing a tremendous challenge in terms of planning and funding recovery packages and to whom they should be targeted. Given the fact that the recovery packages need to be versatile in order to deal with uncertainties surrounding 
the future prospects of the pandemic, the risk of future "waves," and the timetable for the production of vaccine, governments should continue with a green stimulus recovery that does not require: first, economic sacrifice, and second, an increase in overall expenditure (ADB, 2020b). This includes the promotion of direct investment, policy change, and capacity building. Focusing on sustainable economic recovery, green stimulus packages can subsequently be used to enhance the capacity of the industry to build low-carbon technologies, such as photovoltaic and wind, autonomous cars, heating systems, and efficiency-improving equipment. The development of such low-carbon and sustainable COVID-19 recovery package would also assist Developing Member Country's (DMC) of ADB to fulfill their commitments under key global treaties, such as the 2030 Sustainable Development Agenda, the 2015-2030 Sendai Disaster Risk Mitigation System, and the Paris Agreement.

\subsection{Sustainability practices in production and consumption}

There is an ongoing discussion in many societies about the climate crisis, climate change, global warming, and now, COVID-19. Solutions to the first three linked issues can also help resolve the last one if they are carefully planned (Peters, 2020; Galbraith and Otto, 2020; Steffen et al., 2020). Regardless of significant differences, the COVID-19 pandemic provides chances to pursue the climate agenda along with wider changes in consumption and production in terms of sustainability (Cohen, 2020; Rosenbloom et al., 2020). We recognize that technological advances will only get us part of the way, and there is still a need for significant improvements on the "demand side" (Shove \& Walker, 2010; Alfredsson et al., 2018). Unfortunately, growing levels of consumption (i.e., mass consumption) of goods and services reliant on fossil fuel-based economies have initially always made redundant any new technological advances (Schor, 1999; Sorrell, 2009). The COVID-19 epidemic, on the other hand, presents a chance to rethink individual and societal consumption behaviors in a more fundamental way.

For example, by slackening the speed of life, there has been a revival in home baking and cooking, growing dependence on e-commerce and remote work as well as restricting unnecessary travel. Not all these developments have, of course, beneficial impacts on emissions of greenhouse gases and other aspects of sustainability. Although some changes may even be transient phenomena, and when constraints are relaxed, such potentially good developments could vanish quickly. The COVID-19 pandemic can serve as a catalyst in the transition process and create conditions for better minimum wages or basic incomes, better balance between work and life, or reduced hours of work, and notions of consciousness (energy use and growing one's own food) and sufficiency (less material accumulation or consumption and travel). The chance we get is to sustain and implement current low-carbon approaches and, far more significantly, to focus very extensively on (and ideally adjust) our requirements.

\subsection{Global coordination}

The global catastrophe of COVID-19 is also a reminder that only through coordinated international action can shocks, pandemics, economic crises, and climate-related disasters be resolved. Globally, coordinated action represents a unique opportunity for the worlds' most powerful leaders and business executives to create low-carbon models for business (for example, with the nation becoming a stockholder), and encouraging existing or new supporters (for example, developing new low-carbon innovator funding programs). The COVID-19 pandemic has particularly overwhelmed developing countries that could experience economic collapse and an emission gap for a longer period of time (World Bank, 2020a) without the cooperation of key stakeholders. As a result, in the aftermath of the global shock of the COVID19 pandemic, there is a need to create large coalitions of players (innovators, advocacy groups, and new companies, among others) who can facilitate low-carbon pathways (Meckling et al., 
2015). Here, the challenge is great, but the mission is clear. Human civilizations need to stand together and go forward in the struggle against the COVID-19 pandemic, economic downturn, and climate change.

\section{Conclusion}

The pandemic is closely linked to the climate crisis, in the sense that the pandemic has dictated the amount and type of energy consumption and the subsequent levels of $\mathrm{CO}_{2}$ emissions. If the strategies and policies devised for low-carbon pathways do not take the form of incentive bundles or packages in response to the COVID-19 pandemic, pollution levels could rebound and even exceed the predicted levels for 2030, even though the economy might be poorer (Climate Action Tracker, 2020). Countries therefore have an unparalleled opportunity to use the requisite government initiatives and stimuli in order to foster a prosperous, resilient, and inclusive future, and challenge the climate crisis. In light of the severity of risks, including the pandemic and climate and disaster risk, policymakers should change their priorities and develop effective and enforceable processes that lead to decisive solutions. Countries should use the recovery process as a way to drive investment and behavioral improvements that will force economies to take a low-carbon direction, while resolving structural weaknesses and improving resilience at the same time. This study is affected by some limitations. First, an empirical analysis is completely absent, therefore the findings obtained need to be empirically tested. Second, the focus was on the overall and general global situation, whereas it would be helpful to discuss local or more specific contexts where COVID-19 had had such a huge impact. The indicated limitations would be minimized by future studies that will be detailed and quantitative in nature.

\section{References}

ADB (Asian Development Bank), 2020a. COVID-19 Economic Impact Assessment Template. Available at: https://data.adb.org/taxonomy/term/391

ADB (Asian Development Bank), 2020b. COVID-19 Recovery: A Pathway to a Low-Carbon and Resilient Future. Available at: https://www.adb.org/sites/default/files/publication/625476/covid-19-recovery-lowcarbon-resilient-future.pdf [accessed on 10th November 2020].

Ahmad, T., \& Zhang, D. (2020). A critical review of comparative global historical energy consumption and future demand: The story told so far. Energy Reports, 6, 1973-1991.

Alfredsson, E., Bengtsson, M., Brown, H. S., Isenhour, C., Lorek, S., Stevis, D., \& Vergragt, P. (2018). Why achieving the Paris Agreement requires reduced overall consumption and production. Sustainability: Science, Practice and Policy, 14(1), 1-5.

Arabi, Y.M., Deeb, A.M., Al-Hameed, F., Mandourah, Y., Almekhlafi, G.A., Sindi, A.A., AlOmari, A., Shalhoub, S., Mady, A., Alraddadi, B., Almotairi, A.A., Khatib, K., Abdulmomen, A., Qushmaq, I., Solaiman, O., Al-Aithan, A.M., Al-Raddadi, R., Ragab, A.A., Harthy, A., Kharaba, A., Jose, J., Dabbagh, T., Fowler, R.A., Balkhy, H.H., Merson, L., \& Hayden, F.G., 2019. Macrolides in critically ill patients with Middle East Respiratory Syndrome. International Journal of Infectious Diseases, 81, 184-190. https://doi.org/10.1016/j.ijid.2019.01.041.

Ashour, H. M., Elkhatib, W. F., Rahman, M., \& Elshabrawy, H. A., 2020. Insights into the recent 2019 novel coronavirus (SARS-CoV-2) in light of past human coronavirus outbreaks. Pathogens, 9(3), 186. https://doi.org/10.3390/pathogens9030186.

Baldwin, R., \& Di Mauro, B.W., 2020. Economics in the Time of COVID-19. A VoxEU.org Book, Centre for Economic Policy Research, London. Available at: https://voxeu.org/system/files/epublication/COVID-19.pdf [accessed on 4 June 2020]. 
Barboza, Y., 2020. Coronavirus shutdowns are lowering greenhouse gas emissions; history shows they'll roar back. Los Angeles Times, March 19.

https://www.latimes.com/environment/story/2020-03-19/coronavirus-shutdowns-arelowering-greenhouse-emissions-history-shows-theyll-come-roaring-back [accessed on 4 June 2020].

Bloom, E., De Wit, V., \& Carangal-San Jose, M. J., 2005. Potential economic impact of an avian flu pandemic on Asia. ERD policy brief, No. 42. Available at: https://www.thinkasia.org/bitstream/handle/11540/2165/pb042.pdf?sequence $=1$.

Brakman, S., Garretsen, H., \& van Witteloostuijn, A. (2020). The turn from just-in-time to just-in-case globalization in and after times of COVID-19 An essay on the risk reappraisal of borders and buffers. Social Sciences \& Humanities Open, 100034.

Broom, D., 2020. These 3 charts show what COVID-19 has done to global energy demand. The World Economic Forum COVID Action Platform. Available at: https://www.weforum.org/agenda/2020/08/covid19-change-energy-electricity-uselockdowns-falling-demand/ [accessed on 3 August, 2020].

Buck, T., Arnold, M., Chazan, G., \& Cookson, C., 2020. Coronavirus declared a pandemic as fears of economic crisis mount. Available at: https://www.ft.com/content/d72f1e546396-11ea-b3f3-fe4680ea68b5 [accessed on 19 March 2020].

Burkert, A., \& Loeb, A., 2020. Flattening the COVID-19 curves. Scientific American Blog Network. Available at: https://blogs.scientificamerican [accessed on 17 March, 2020].

Chakraborty, I., \& Maity, P., 2020. COVID-19 outbreak: Migration, effects on society, global environment and prevention. Science of the Total Environment, 138882. https://doi.org/10.1016/j.scitotenv.2020.138882.

Chou, J., Kuo, N. F., \& Peng, S. L., 2004. Potential impacts of the SARS outbreak on Taiwan's economy. Asian Economic Papers, 3(1), 84-99.

Climate Action Tracker, 2020. A government roadmap for addressing the climate and post COVID-19 economic crises. Available at: https://climateactiontracker.org/publications/addressing-the-climate-and-post-covid-19economic-crises/ [accessed on 27 April, 2020].

Cohen, M. J., 2020. Does the COVID-19 Outbreak Mark the Onset of a Sustainable Consumption Transition? Sustainability: Science, Practice and Policy, 16(1): 1-3. doi:10.1080/15487733.2020.1740472.

Cooperation, E.M., 2015. The Outlook for Energy: A View To 2040. Exxon Mobil Cooperation, http://dx.doi.org/10.1080/01998595.2012.10491656.

Das, K., \& Paital, B., 2020. The synergy between philosophy and science, need of the contemporary society. Int. J. Humanities Soc. Sci. Res. 6 (1), 45-51.

Deloitte Insights, 2020. Resilient leadership responding to COVID-19. Available at: https://www2.deloitte.com/global/en/insights/economy/covid-19/heart-of-resilientleadership-responding-to-covid-19.html [accessed on 20 March, 2020].

Di Mauro, B.W., 2020. Macroeconomics of the flu. In Baldwin, R. and Di Mauro, B.W. (eds). (2020). Economics in the Time of COVID-19. A VoxEU.org Book, Centre for Economic Policy Research, London. Available at: https://voxeu.org/system/files/epublication/COVID-19.pdf [accessed on 26 March 2020].

Dong, K., Dong, X., \& Jiang, Q., 2020a. How renewable energy consumption lower global $\mathrm{CO} 2$ emissions? Evidence from countries with different income levels. World Econ. 43, 1665-1698. http://dx.doi.org/10.1111/twec.12898.

Dong, L., Hu, S., \& Gao, J., 2020b. Discovering drugs to treat coronavirus disease 2019 (COVID-19). Drug Discoveries \& Therapeutics, 14(1), 58-60. https://doi.org/10.5582/ddt.2020.01012 
Dutheil, F., Baker, J. S., \& Navel, V., 2020. COVID-19 as a factor influencing air pollution? Environmental Pollution, 263: 114466. https://dx.doi.org/10.1016\%2Fj.envpol.2020.114466.

Eichengreen, B., 2020. Coronanomics 101: which policy tools will contain the economic threat of COVID-19? World Economic Forum. Available at: https://www.weforum.org/agenda/2020/03/coronavirus-economics/ [accessed on 15 March 2020].

Erken, H., Van Es, F., Every, M., Hayat, R., Ji, K., \& Vogel, S., 2020. Global Economic Contraction: Re-assessing the impact of COVID-19. RaboResearch-Economic Research. Available at: https://economics.rabobank.com/publications/2020/april/globaleconomic-contraction/[accessed on 9 April 2020].

Evans, S., 2020. Analysis: Coronavirus set to cause largest ever annual fall in $\mathrm{CO} 2$ emissions. Retrieved from: https://www.carbonbrief.org/analysis-coronavirus-set-to-cause-largestever-annual-fall-in-co2-emissions [accessed on 4 June 2020].

Fife, R., Graney, E., \& Cryderman, K., 2020. Ottawa Prepares Multibillion-Dollar Bailout of Oil and Gas Sector. The Globe and Mail.

Figueres, C. et al., 2018. Emissions are still rising: ramp up the cuts. Nature, 564, 27-30.

Financial Times, 2020. Can we tackle both climate change and Covid-19 recovery? Available at: https://www.ft.com/content/9e832c8a-8961-11ea-a109-483c62d17528 [accessed on 4 June 2020].

Galbraith, E., \& Otto, R., 2020. Coronavirus response proves the world can act on climate change. The Conversation.

German Council of Economic Experts (GCEE), 2020. Die Gesamtwirtschaftliche Lage angesichts der Cornona- Pandemie (The Overall Economic Situation in View of the Corona Pandemic). Weisbaden: GCEE.

Guan, W. J., Ni, Z. Y., Hu, Y., Liang, W. H., Ou, C. Q., He, J. X., ... \& Du, B., 2020. Clinical characteristics of coronavirus disease 2019 in China. New England Journal of Medicine, 382(18), 1708-1720. doi: 10.1056/NEJMoa2002032.

Hai, W., Zhao, Z., Wang, J., \& Hou, Z. G., 2004. The short-term impact of SARS on the Chinese economy. Asian Economic Papers, 3(1), 57-61.

Harapan, H., Itoh, N., Yufika, A., Winardi, W., Keam, S., Te, H., Megawati, D., Hayati, Z., Wagner, A.L., \& Mudatsir, M., 2020. Coronavirus disease 2019 (COVID-19): a literature review. Journal of Infection and Public Health. https://doi.org/10.1016/j. jiph.2020.03.019 [accessed on 4 June 2020].

Henriques, M., 2020. Will Covid-19 have a lasting impact on the environment? Available at: https://www.bbc.com/future/article/20200326-covid-19-the-impact-of-coronavirus-onthe-environment [accessed on 4 June 2020].

https://www.iea.org/reports/global-energy-review-2020/global-energy-and-co2emissions-in 2020 [accessed on April, 2020].

Huang, C., Wang, Y., Li, X., Ren, L., Zhao, J., Hu, Y., et al., 2020. Clinical features of patients infected with 2019 novel coronavirus in Wuhan, China. The Lancet, 395, 497506. https:// doi.org/10.1016/S0140-6736 (20)30183-5.

IEA, 2017. Report: World energy outlook 2017. Available at: http://dx.doi.org/10.1787/weo2017-en.

IEA, 2019. Global CO2 Emissions in 2019. Available at: https://www.iea.org/articles/globalco2- emissions-in-2019.

IEA, 2020a. Exploring the impacts of the Covid-19 pandemic on global energy markets, energy resilience, and climate change. Available at: https://www.iea.org/topics/covid19 
IEA, 2020b. Global Energy Review 2020: The impacts of the Covid-19 crisis on global energy demand and CO2 emissions. Available at: https://www.iea.org/reports/globalenergy-review-2020/electricity\#abstract [accessed in April, 2020].

IEA, 2020c. The impacts of the Covid-19 crisis on global energy demand and CO2 emissions.

International Monetary Fund (IMF), 2020. World Economic Outlook. Available at: https://www.imf.org/en/ Publications/WEO/Issues/2020/04/14/weo-april-2020 [accessed on $14^{\text {th }}$ April, 2020].

IPCC, 2014. Climate Change 2014: Synthesis Report. Cambridge: Cambridge University Press.

Kohl, W. L. (2019). The International Energy Agency: The Political Context. Oil, The Arabisrael Dispute, And The Industrial World, 246-257.

Kona, A., Bertoldi, P., Monforti-Ferrario, F., Rivas, S., \& Dallemand, J.F., 2018. Covenant of mayors signatories leading the way towards 1.5 degree global warming pathway. Sustainable Cities and Societies, 41, 568-575. http://dx.doi.org/10. 1016/j.scs.2018.05.017.

Krugman, P., 2020. Republicans Don't Want to Save Jobs - Billions for oil, nothing for nurses and teachers. The New York Times, April 13.

Le Quéré, C. et al., 2019. Drivers of declining CO2 emissions in 18 developed economies. Nature Climate Change, 9, 213-217.

Le Quéré, C., Jackson, R. B., Jones, M. W., Smith, A. J., Abernethy, S., Andrew, R. M., \& Friedlingstein, P., 2020. Temporary reduction in daily global $\mathrm{CO}_{2}$ emissions during the COVID-19 forced confinement. Nature Climate Change, 10, 647-653.

Lee, J. W., \& McKibbin, W. J., 2004. Globalization and disease: The case of SARS. Asian Economic Papers, 3(1), 113-131.

Letzing, J., 2020. How many policy tools are left to soften the impact of COVID-19? World Economic Forum. Available at: https://www.weforum.org/agenda/2020/03/covid-19coronavirus-policy-tools-economic-impact/ [accessed on 27 March 2020].

Loayza, N. V., 2020. Costs and Trade-Offs in the Fight against the COVID-19 Pandemic: A Developing Country Perspective. World Bank Group. Open Knowledge Repository.

Mandal, I., \& Pal, S., 2020. COVID-19 pandemic persuaded lockdown effects on environment over stone quarrying and crushing areas. Science of the Total Environment, 732, 139281.

Mavrokefalidis, D., 2020. Global CO2 emissions dive $8.8 \%$ in first half of 2020. Available at: https://www.energylivenews.com/2020/10/14/global-co2-emissions-dive-8-8-in-firsthalf-of-2020/ [accessed on 14 October, 2020].

McCloskey, B., \& Heymann, D. L., 2020. SARS to novel coronavirus-old lessons and new lessons. Epidemiology \& Infection, 148, e22.

McCollum, D. L., Gambhir, A., Rogelj, J. \& Wilson, C., 2020. Energy modellers should explore extremes more systematically in scenarios. Nature Energy, 5, 104-107.

McGrath, M., 2020. Climate change and coronavirus: Five charts about the biggest carbon crash. Science and Environment. Available at: https://www.bbc.com/news/scienceenvironment-52485712 [accessed on 4 June 2020].

McKibbin, W., \& Fernando, R., 2020. The economic impact of COVID-19. In: Baldwin R, Di Mauro BW, eds. Economics in the time of COVID-19. London CEPR Press, pp. 4552.

Meckling, J., Kelsey, N., Biber, E., \& Zysman, J., 2015. Climate Change: Winning Coalitions for Climate Policy. Science, 349(6253), 1170-1171. doi: 10.1126/science.aab1336. 
Mostafa, M. K., Gamal, G., \& Wafiq, A. 2020. The impact of COVID 19 on air pollution levels and other environmental indicators-A case study of Egypt. Journal of environmental management, 277, 111496.

Mulvaney, K., 2019. Climate change report card: These countries are reaching targets. National Geographic. Available at: https://www.nationalgeographic.co.uk/environmentand-conservation/2019/09/climate-change-report-card-these-countries-are-reaching (accessed on 24 September 2019).

Murphy-Gregory, H, 2018. NGOs and global economic policy institutions, Handbook of Research on NGOs, Edward Elgar Publishing Ltd., A Kellow and H Murphy-Gregory (ed), Cheltenham, UK, pp. 180-195.

Omer, M.A.B., \& Noguchi, T., 2020. A conceptual framework for understanding the contribution of building materials in the achievement of sustainable development goals (SDGs). Sustainable Cities and Societies, 52. Available at: http://dx.doi.org/10.1016/ j.scs.2019.101869.

Paital, B., 2020. Nurture to nature via COVID-19, a self-regenerating environmental strategy of environment in global context. Science of the Total Environment, 139088. Available at: https://doi.org/10.1016/j.scitotenv.2020.139088.

Peters, G. P. et al., 2020. Carbon dioxide emissions continue to grow amidst slowly emerging climate policies. Nature Climate Change, 10, 3-6.

Peters, G. P., Minx, J. C., Weber, C. L. \& Edenhofer, O., 2011. Growth in emission transfers via international trade from 1990 to 2008. Proceedings of the National Academy of Sciences of the United States of America, 108, 8903-8908.

Petro, G., 2020. The Coronavirus Tsunami: What's To Come for U.S. Retail. Forbes. Available at: https://www.forbes.com/sites/gregpetro/2020/03/20/the-coronavirustsunami-whats-to-come-for-us-retail/\#128e4da6609d [accessed on 26 March 2020].

Pietrosemoli, L., \& Rodríguez-Monroy, C., 2019. The Venezuelan energy crisis: Renewable energies in the transition towards sustainability. Renewable and Sustainable Energy Reviews, 105, 415-426. http://dx.doi.org/10.1016/j.rser.2019.02.014.

Pongpirul, W. A., Pongpirul, K., Ratnarathon, A. C., \& Prasithsirikul, W., 2020. Journey of a Thai taxi driver and novel coronavirus. New England Journal of Medicine, 382(11), 1067-1068. doi: 10.1056/NEJMc2001621.

Rosenbloom, D., Markard, J., Geels, F. W., \& Fuenfschilling, L., 2020. Opinion: Why carbon pricing is not sufficient to mitigate climate change - and how "sustainability transition policy" can help. Proceedings of the National Academy of Sciences, 117(16), 86648668.

Saadat, S., Rawtani, D., \& Hussain, C. M., 2020. Environmental perspective of COVID19. Science of the Total Environment, 138870. https://doi.org/10.1016/j.scitotenv.2020.138870.

Schor, J. B., 1999. The Overspent American: Why We Want What We Don't Need. New York: Harper Perennial.

Shakil, M. H., Munim, Z. H., Tasnia, M., \& Sarowar, S. (2020). COVID-19 and the environment: A critical review and research agenda. Science of the Total Environment, 141022.

Shove, E. \& Walker, G. (2010). Governing Transitions in the Sustainability of Everyday Life. Research Policy 39 (4): 471-476. doi:10.1016/j.respol. 2010.01.019.

Silverstein, W. K., Stroud, L., Cleghorn, G. E., \& Leis, J. A., 2020. First imported case of 2019 novel coronavirus in Canada, presenting as mild pneumonia. The Lancet, 395(10225), 734. https://doi.org/10.1016/S0140-6736(20)30370-6.

Siu, A., \& Wong, Y. R., 2004. Economic impact of SARS: the case of Hong Kong. Asian Economic Papers, 3(1), 62-83. 
Sohrabi, C. et al., 2020. World Health Organization declares global emergency: a review of the 2019 novel coronavirus (COVID-19). International Journal of Surgery, 76, 71-76.

Solaymani, S., 2019. $\mathrm{CO}_{2}$ emissions patterns in 7 top carbon emitter economies: the case of transport sector. Energy, 168, 989-1001.

Sönnichsen, N., 2020. Coronavirus: impact on the global energy industry - Statistics \& Facts. Available at: https://www.statista.com/topics/6254/coronavirus-covid-19-impact-onthe-energy-industry/\#dossierSummary_chapter4 [accessed on 10 September, 2020].

Sorrell, S., 2009. Jevons' Paradox revisited: The evidence for backfire from improved energy efficiency. Energy Policy, 37(4), 1456-1469.

Sruthi, S. 2020. COVID-19 Impact and Responses, 2020. Bhumi Publishing, India. https://www.bhumipublishing.com/wp-content/uploads/2020/08/COVID\%E2\%80\%93-19-Impact-and-Response.pdf .

Steffen, B., Egli, F., Pahle, M., \& Schmidt, T. S., 2020. Navigating the Clean Energy Transition in the COVID-19 Crisis. Joule, 4(6), 1137-1141.

Stylianou, N., Guibourg, C., Dunford, D., Rodgers, L. Brown, D, \& Rincon, D., 2020. Climate change: Where we are in seven charts and what you can do to help. BBC News. January 14. Available at: https://www.bbc.com/news/science-environment46384067 [accessed on 4 June 2020].

The Indian Express, 2020. Explained: How Covid-19 lockdowns have impacted the global energy sector. Available at: https://indianexpress.com/article/explained/covid-19lockdown-impact-global-energy-sector-demand-explained-6386515/ [accessed on 2 May 2020].

United Nations, 2015. Resolution adopted by General Assembly on 25 September 2015 Transforming our world: the 2030 Agenda for Sustainable Development. In: Gen. Assem. 70th Sess. A/RES/70/1, pp. 1-35. https://doi.org/10.1007/s13398-014-0173-7.2

Velavan, T. P., \& Meyer, C. G., 2020. The COVID-19 epidemic. Tropical Medicine \& International Health, 25(3), 278. https://dx.doi.org/10.1111\%2Ftmi.13383.

Watts, J., 2020. Climate crisis: in coronavirus lockdown, nature bounces back - but for how long? The Guardian. Available at: https://www.theguardian.com/world/2020/apr/09/climate-crisis-amid-coronaviruslockdown-nature-bounces-back-but-for-how-long [accessed on 4 June 2020].

WHO, 2020. Rolling updates on coronavirus disease (COVID-19). Available at: https://www.who.int/emergencies/diseases/novel-coronavirus-2019/events-as-theyhappen [accessed on $10^{\text {th }}$ November 2020].

World Bank, 2020. Europe and Central Asia Economic Update, Fall 2020: COVID-19 and Human Capital. World Bank, USA. Available at: https://openknowledge.worldbank.org/handle/10986/34518 [accessed on $10^{\text {th }}$ November 2020].

World Bank, 2020a. East Asia and Pacific: Countries Must Act Now to Mitigate Economic Shock of COVID-19. Available at: https://www.worldbank.org/en/news/pressrelease/2020/03/30/east-asia-and-pacific-countries-must-act-now-to-mitigateeconomic-shock-of-covid-19 [accessed on 4 June 2020].

World Bank, 2020b. Global Economic Prospects. Available at: https://openknowledge.worldbank.org/handle/10986/33748 [accessed in June 2020].

Yu, K. D. S., \& Aviso, K. B., 2020. Modelling the economic impact and ripple effects of disease outbreaks. Process Integration and Optimization for Sustainability, 4,183-186.

Zambrano-Monserrate, M. A., Ruano, M. A., \& Sanchez-Alcalde, L., 2020. Indirect effects of COVID-19 on the environment. Science of the Total Environment, 138813. 
Zhou, F., Yu, T., Du, R., Fan, G., Liu, Y., Liu, Z., ..., \& Guan, L., 2020. Clinical course and risk factors for mortality of adult inpatients with COVID-19 in Wuhan, China: a retrospective cohort study. The Lancet. https://doi.org/10.1016/S0140-6736(20)305663.

Zuberi, M.A. 2011. Oil prices rebound as US gasoline stocks fall. Business Recorder. https://www.brecorder.com/news/11088/. Accessed on December 14, 2019. 


\section{Authors' Biographies}

Most. Asikha Aktar is an Assistant Professor of Economics at Comilla University, Bangladesh. She obtained her Master's degree in Economics from University of Dhaka. Recently, she enrolled in a PhD program in Economics at Universiti Utara Malaysia (UUM), Malaysia. To date she has published six journal articles and one book chapter. Her research areas include sustainable development, energy economics, and climate change.

Dr. Md. Mahmudul Alam is an Associate Professor at Universiti Utara Malaysia (UUM). He is also an Associate Fellow at University Technology MARA (Malaysia). He was awarded the AFFP Research Fellowship from FS-UNEP Centre (Germany) and is recognized by the BDRC (USA) as one of the "Top Bangladesh Development Researchers of the Millennium". He obtained his $\mathrm{PhD}$ and Master's degrees from National University of Malaysia (UKM). To date he has published 100+ journal articles and presented 100+ articles at conferences. His research areas include sustainable finance, sustainable development, ecological economics, financial economics, fintech, and Islamic finance and economics.

Dr. Abul Quasem Al-Amin is a Professor (Adjunct) at the Geography and Environmental Management, Faculty of Environment, University of Waterloo. He is also Director of the Centre for Asian Climate and Environmental Policy Studies, Canada. Prof. Al-Amin is currently associated with many research works at UNDP, HEKS, HAW-Germany, Springer USA, FORUM FOR FUTURE Singapore, Ministry of Natural Resources and Environment Malaysia, Malaysian Biotechnology Corporation, Economic Planning Unit Malaysia, Country representative of Malaysia to UNFCCC, Academy Science Malaysia, Economic Research Institute for ASEAN and East Asia and Sime Darby Malaysia. Prof. Al-Amin is assisting countries, especially ASEAN in accelerating the transition to a low-carbon economy through enhancing policymakers' capacity to promote green technologies. 